\title{
A rare complication of azotemic hyperparathyroidism Ischemic calcific myopathy
}

Figure Clinical and pathologic findings in ischemic calcific myopathy

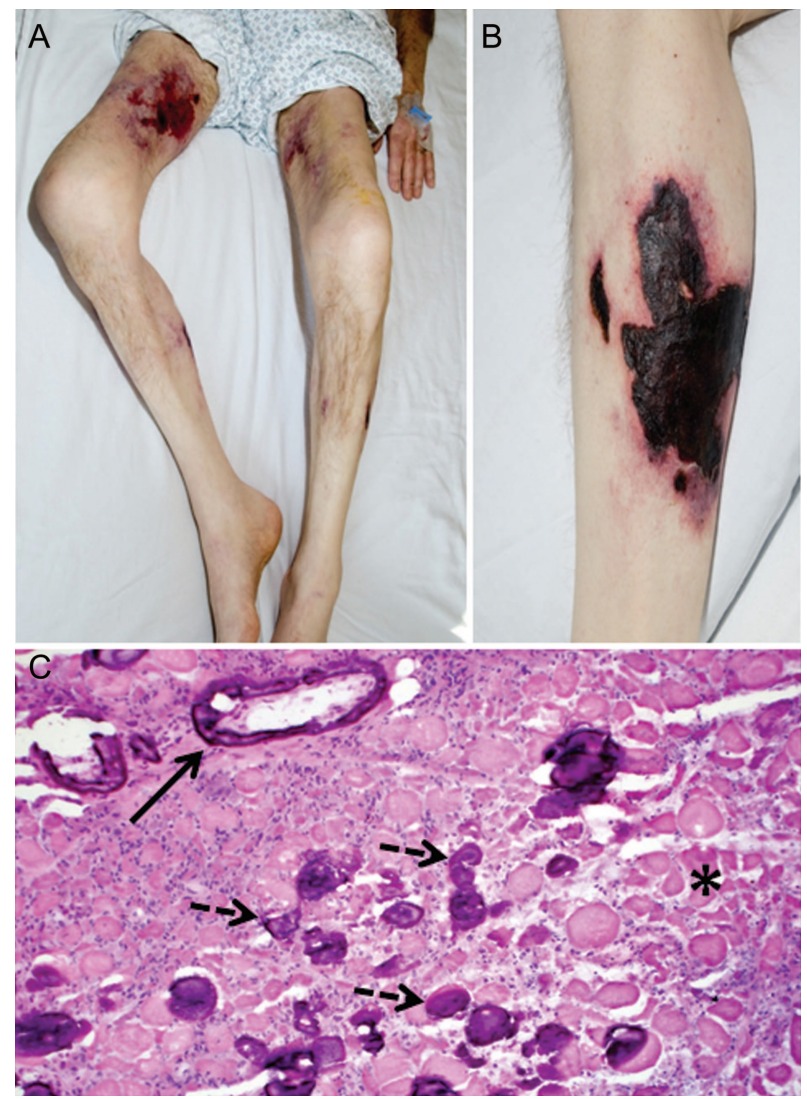

(A) Profound diffuse muscle atrophy with scattered ecchymoses. (B) Eschar-like lesions with surrounding erythema representing biopsy proven calciphylaxis. (C) Calcium deposition within muscle fibers (dashed arrows) and vessel walls (solid arrow), and multifocal infarcts evidenced by muscle fibers without nuclei (asterisk) (hematoxylin-eosin).

A 50-year-old man with metastatic parathyroid carcinoma and chronic renal insufficiency presented after 3 months of myalgias, progressive proximal muscle weakness and atrophy, and leg skin lesions resembling eschars (figure). Serum CK (556 U/L; normal 52-336) and parathyroid hormone (3,305 pg/mL; normal 15-50) levels were elevated; calcium was well-controlled on cinacalcet monotherapy. EMG demonstrated diffuse myopathy. Muscle biopsy revealed multifocal infarcts and calcium deposition primarily within vessel walls. Skin biopsy showed changes consistent with calciphylaxis. Steroids and plasma exchange provided no benefit. Ischemic calcific myopathy is rare ${ }^{1,2}$ but should be considered in patients with proximal muscle weakness and uremic hypercalcemia.

Gabriele C. De Luca, MD, PhD, Scott D.Z. Eggers, MD, Rochester, $M N$

Disclosure: The authors report no disclosures.

Address correspondence and reprint requests to Dr. Scott D.Z. Eggers, Mayo Clinic College of Medicine, Mayo Building, 8th floor, 200 First Street SW, Rochester, MN 55905; eggers.scott@mayo.edu

1. Richardson JA, Herron G, Reitz R, Layzer R. Ischemic ulcerations of skin and necrosis of muscle in azotemic hyperparathyroidism. Ann Intern Med 1969;71:129-138.

2. Flanigan $\mathrm{KM}$, Bromberg MB, Gregory M, et al. Calciphylaxis mimicking dermatomyositis: ischemic myopathy complicating renal failure. Neurology 1998;51:1634-1640. 


\section{Neurology}

\section{A rare complication of azotemic hyperparathyroidism: Ischemic calcific myopathy Gabriele C. De Luca and Scott D.Z. Eggers \\ Neurology 2010;75;1942 \\ DOI 10.1212/WNL.0b013e3181feb2d5}

This information is current as of November 22, 2010

Updated Information \&

Services

References

Subspecialty Collections

Permissions \& Licensing

Reprints including high resolution figures, can be found at: http://n.neurology.org/content/75/21/1942.full

This article cites 2 articles, 1 of which you can access for free at: http://n.neurology.org/content/75/21/1942.full\#ref-list-1

This article, along with others on similar topics, appears in the following collection(s):

All Clinical Neurology

http://n.neurology.org/cgi/collection/all_clinical_neurology All Medical/Systemic disease

http://n.neurology.org/cgi/collection/all_medical_systemic_disease Endocrine

http://n.neurology.org/cgi/collection/endocrine

Muscle disease

http://n.neurology.org/cgi/collection/muscle_disease

Information about reproducing this article in parts (figures,tables) or in its entirety can be found online at:

http://www.neurology.org/about/about_the_journal\#permissions

Information about ordering reprints can be found online:

http://n.neurology.org/subscribers/advertise

Neurology ${ }^{\circledR}$ is the official journal of the American Academy of Neurology. Published continuously since 1951, it is now a weekly with 48 issues per year. Copyright Copyright (? 2010 by AAN Enterprises, Inc.. All rights reserved. Print ISSN: 0028-3878. Online ISSN: 1526-632X.

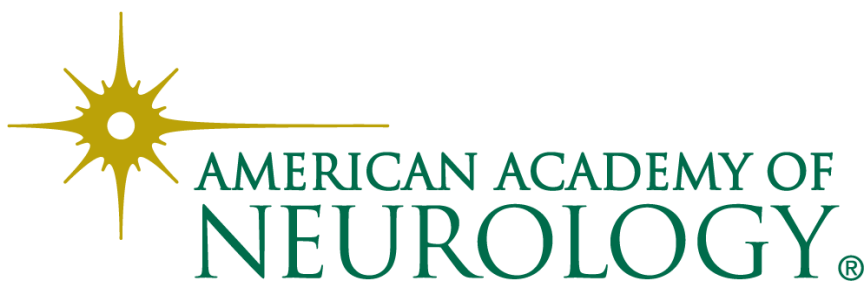

